\title{
Algengi ípróttameiðsla, ípróttapátttaka og brottfall vegna meiðsla hjá 17 og 23 ára ungmennum
}

\begin{abstract}
Margrét H. Indriðadóttir ${ }^{1}$ sjúkrapjálfari, Pórarinn Sveinsson² lífeðlisfræðingur, Kristján Pór Magnússon ${ }^{1}$ faraldsfræðingur,
\end{abstract} Sigurbjörn Árni Arngrímsson ${ }^{1}$ pjálfunarlífeðlisfræðingur, Erlingur Jóhannsson ${ }^{1}$ lífeðlisfræðingur

\section{ÁGRIP}

Inngangur: Pátttaka i ípróttum og líkamsrækt hefur farið vaxandi undanfarna áratugi og ípróttameiðsli pví orðin algengari. Tilgangur rannsóknarinnar var að meta algengi ípróttameiðsla og brottfall vegna peirra. Að auki var tilgangurinn að skoða hvort ípróttameiðsli hefðu tengsl við kyn, aldur, prek, holdafar og ið̌kun sem var meiri en 6 klukkustundir á viku, miðað við 6 klukkustundir eða minna.

Efniviður og aðferðir: Rannsóknin var pversniðsrannsókn á 457 ungmennum, 17 og 23 ára. Hæð, pyngd, líkamsfita, fitulaus mjúkvefjamassi, beinmassi og prek (W/kg) voru mæld en spurningalisti notaður til pess að meta pátttöku i ípróttum og líkamsrækt, algengi ípróttameiðsla og brottfall.

Niðurstöður: Fjögurhundruð og fjörutíu (96\%) höfðu einhvern tímann stundað ípróttir með ípróttafélagi en $277(63 \%)$ voru hætt, fleiri $(\mathrm{p}=0,058)$ í hópi stúlkna (67,6\%) en drengja (58,8\%). Prjátíu og sjö $(8,4 \%)$ hættu vegna íbróttameiðsla. Af peim sem æfðu með íbróttafélagi síðastliðna 12 mánuði voru $51 \%$ sem purftu læknisfræðilega aðstoð einu sinni eða oftar vegna ípróttameiðsla. Peir sem æfðu meira en 6 klukkustundir á viku höfðu fimmfalt hærra líkindahlutfall pess að hafa leitað læknisfræðilegrar aðstoðar (OR $=5,30 ; 95 \%$ Cl: 3,00-9,42) en peir sem æfðu 6 klukkustundir eða minna.

Ályktun: Ípróttameiðsli eru talsvert vandamál sem geta valdið brottfalli úr ípróttum. Áhættupætti ípróttameiðsla parf að rannsaka betur svo hægt verði að efla forvarnir og tryggja pjálfun sem byggir á gagnreyndum aðferðum.
Fyrirspurnir: Erlingur Jóhannsson erljo@hi.is

Greinin barst 13. febrúar 2015 sampykkt til birtingar 8. september 2015

\section{Inngangur}

Pátttaka barna og unglinga í skipulögðum ípróttum hefur farið vaxandi undanfarna áratugi. ${ }^{1}$ Gildi hreyfingar og félagsstarfs fyrir líkamlega, andlega og félagslega heilsu er ótvírætt, ${ }^{2,3}$ en með vaxandi pátttöku og aukinni tíðni æfinga og keppni eru ípróttameiðsli orðin að umtalsverðu heilbrigðisvandamáli. ${ }^{4-11}$ Flest ípróttameiðsli eru pó væg ${ }^{4,12}$ en hlutfall alvarlegra meiðsla er um pað bil $15 \% .{ }^{13}$ Hluti peirra getur haft afleiðingar til lífstíðar og valdið skerðingu á lífsgæðum og líkamlegri virkni. ${ }^{1,6,8}$ Ekki er talið að alvarlegum meiðslum hafi fjölgað hlutfallslega síðustu tvo áratugi, ${ }^{13}$ pótt fyrir liggi vísbendingar um aukna tíðni höfuðmeiðsla og slits á fremra krossbandi í hné. ${ }^{12}$ Eftir krossbanda- og liðpófaaðgerðir er algengt að fólk prói með sér slitgigt ${ }^{14}$ og samkvæmt nýrri rannsókn ${ }^{15}$ höfðu peir sem fóru í slíkar aðgerðir 7 sinnum hærra nýgengi gerviliðaaðgerða í hné en samanburðarhópur, 15 árum síðar. Vaxtarlínuáverkar verða í 38\% tilvika vegna ípróttameiðsla en vaxtartruflanir og aflaganir fylgja vaxtarlínuáverkum í $15 \%$ tilfella. ${ }^{1}$

Lítið er um rannsóknir á algengi ípróttameiðsla barna og unglinga og mismunandi skilgreiningar á ípróttameiðslum torvelda samanburð á niðurstöðum rannsókna á pessu sviði. Erlendar pversniðsrannsóknir par sem spurt var um ípróttameiðsli síðastliðna 12 mánuði sýndu að 50-61\% pátttakenda í skipulögðu ípróttastarfi höfðu að minnsta kosti meitt sig einu sinni í ípróttum á tímabilinu. ${ }^{4,5,10,11}$ Framskyggnar rannsóknir sýna nýgengishlutfall á bilinu 2,08/1000 æfingar og/eða kappleiki (ÆK) til 6,31/1000 ÆK og hlutfallið er hærra meðal drengja en stúlkna. ${ }^{16-18}$ Rannsókn á alvarlegum ípróttameiðslum sýnir nýgengishlutfall 0,45/1000 ÆK hjá drengjum, 0,26/1000 ÆK hjá stúlkum og 0,39/1000 ÆK í heildina. ${ }^{13}$ Tölur um algengi brottfalls vegna ípróttameiðsla hafa ekki verið birtar í ritrýndum tímaritum svo vitað sé til.

Hætta á ípróttameiðslum ungmenna er mismunandi eftir ípróttagreinum en komið hefur fram að hún sé almennt minni við ástundun einstaklingsíprótta en liðaíprótta. ${ }^{11}$ Viðamestu rannsóknirnar á nýgengi i mismunandi ípróttagreinum eru á bandarísku pýði og mælist hæst í amerískum fótbolta, glímu, fimleikum, íshokkí, fótbolta og körfubolta. Pess má geta að handbolti er mjög lítið stundaður par um slóðir og pví ekki meðal peirra ípróttagreina sem rannsóknirnar taka til.12,13,16 Hættan er líka meiri við keppni en æfingar. ${ }^{12,13,17}$ Haldgóðar vísbendingar eru um að fyrri meiðsli hafi forspárgildi fyrir endurtekin meiðsli af sama toga ${ }^{19}$ en rannsóknir sýna að um 50\% unglinga sem lentu í meiðslum höfðu meiðst áður. ${ }^{4,5}$ Pá reyndust unglingar sem æfa allt árið vera í $43 \%$ meiri hættu á álagsmeiðslum en peir sem fengu hvíld frá ípróttinni í prjá mánuði á ári. ${ }^{10}$

Vísbendingar eru um að iðkun íprótta og líkamsræktar á bernsku- og unglingsárum geti haft forspár- 
gildi um líkamlega virkni á fullorðinsárum. ${ }^{20}$ Pví er til mikils að vinna að viðhalda pátttöku barna og unglinga í ípróttum og líkamsrækt eins lengi og kostur er, pví hreyfingarleysi er talið stærsta lýðheilsuvandamál 21. aldarinnar., ${ }^{2,3}$

Markmið pessarar rannsóknar var að greina pátttöku ungmenna í ípróttum og líkamsrækt, algengi ípróttameiðsla og brottfall vegna peirra. Að auki var markmiðið að skoða hvort ípróttameiðsli hefðu tengsl við kyn, aldur, prek, holdafar og pess að stunda ípróttir og líkamsrækt í meira en 6 klukkustundir á viku miðað við 6 klukkustundir eða minna.

\section{Efniviður og aðferðir}

Rannsóknin er pversniðsrannsókn og ein af mörgum sem er byggð á gögnum úr rannsókninni Atgervi ungra Íslendinga sem er langtímaheilsufarsrannsókn á ungmennum fæddum 1988 og 1994. Leitað var eftir pátttöku einstaklinga sem tóku pátt í sams konar rannsókn og bar heitið Lífsstíll 9 og 15 ára Íslendinga og framkvæmd var skólaárið 2003-2004. Tilgangur rannsóknarinnar er pví að rannsaka langtíma- og aldurshópabreytingar á heilsutengdum páttum eins og holdafari, hreyfingu, preki, andlegri líðan og félagslegum páttum.

\section{Dátttakendur}

Pátttakendur voru 457 ungmenni, 17 og 23 ára, sem höfðu tekið pátt í íslenskum hluta European Youth Heart Study árið 2003, pá 931 talsins. Úrtakið í peirri rannsókn, sem nefndist Lífsstíll 9 og 15 ára Íslendinga, var af höfuðborgarsvæðinu (60\%), frá péttbýliskjörnum á landsbyggðinni (35\%) og úr dreifbýli (5\%). Aldurs- og kynjaskiptingu úrtaks má sjá í töflu I. Frá höfuðborgarsvæðinu komu $67 \%$ en 33\% frá Akureyri, Egilsstöðum og Húsavík. Rannsóknin var sampykkt af Vísindasiðanefnd (VSNa2003060014/03.1) og tilkynnt til Persónuverndar og Geislavarna ríkisins.

\section{Aðferðir}

Mælingar fóru fram á Heilbrigðisstofnun Austurlands, Heilbrigðisstofnun Pingeyinga, Fjórðungssjúkrahúsinu á Akureyri og Rannsóknarstöð Hjartaverndar, á tímabilinu ágúst 2011 til janúar 2012.

\section{Holdafar}

Líkamspyngd var mæld með 0,1 kg nákvæmni, með viðurkenndum pyngdarmæli (Seca, Model 813) og hæð með 0,1 sm nákvæmni með viðurkenndum hæðarmæli (Seca, Model 217). Líkamspyngdarstuðull (body mass index, BMI) var reiknaður með pví að deila hæð í öðru veldi í líkamspyngd $\left(\mathrm{kg} / \mathrm{m}^{2}\right)$.

\section{Líkamssamsetning-DXA}

Fitumassi var mældur með DXA beinpéttnimælitæki (Dual Energy X-Ray Absorptiometry) og fituprósenta reiknuð sem hlutfall fitu af líkamspyngd. Fitulaus mjúkvefjamassi (lean soft tissue, LST) og beinmassi var mældur og hlutfall reiknað á sama hátt. DXA- mælingar fóru fram á Fjórðungssjúkrahúsinu á Akureyri (Hologic Discovery QDR 4500) og á Rannsóknarstofu Hjartaverndar (GE Lunar IDXA software 1140.004). Pekkt skekkja er á milli tækjanna og pví var leiðréttingarstuðull notaður við útreikninga.

\section{prek}

Prek var mælt með prepaskiptu hámarksprófi á rafstýrðu prekhjóli (Monark Ergometer 839E, Vansbro, Svípjóð) par sem hvert prep tók prjár mínútur. Prektala $(\mathrm{W} / \mathrm{kg})$ var reiknuð út frá notuðu hámarksafli (Wött) sem hlutfall af líkamspyngd (kg). Hámarksafl $\left(\mathrm{W}_{\max }\right)$ var reiknað út frá jöfnunni:

$\mathrm{W}_{\max }=\mathrm{W}_{1}+\mathrm{W}_{2} / \mathrm{T} / 180$

par sem $W_{1}$ stendur fyrir heildarafl á síðasta stigi sem lokið var að fullu, en $W_{2}$ er aflaukning á lokastigi sem ekki náðist að klára. T er tíminn sem óklárað lokastig tók, mældur í sekúndum. Skilgreining um að hámarksprófi væri nád, var að hámarkspúls næði $\geq 181$ (23 ára) og $\geq 185$ (17 ára) slögum á mínútu og að upplifun áreynslunnar væri $\geq 19$ á Borg-álagsskalanum sem er viðurkenndur alpjóðlegur skali. Рað jafngildir peirri upplifun að ekki séu nema örfáar sekúndur í örmögnun. Ef aðeins annað af pessu náðist var pað mat mælingarmanns hvort hámarksprófi væri náð pegar viðkomandi kaus að hætta. Á hverju stigi var skráð hjartsláttartíðni sem var mæld með práđlausum púlsmæli (Polar Pacer Tester, Kempele, Finnland) og mat pátttakanda á álagi, samkvæmt Borg-álagsskalanum.

\section{Spurningalisti}

Úr víðtækum spurningalista um lífsstíl og líkamlega, andlega og félagslega pætti fengust upplýsingar um prjá meginpætti: Pátttöku í skipulögðu ípróttastarfi og líkamsrækt algengi ípróttameiðsla sem kölluðu á læknisfræðilega aðstoð, síðastliðna 12 mánuði, og algengi ípróttameiðsla sem ollu fjarveru frá æfingum eða keppni, eða brottfalli einhvern tímann á ípróttaferlinum.

Reglubundin hreyfing pátttakenda var mæld á tvo vegu. Fyrri mæling mældi fjölda klukkustunda á viku við iðkun íprótta og/ eða líkamsræktar. Seinni mæling mældi fjölda æfinga- og keppnisdaga á viku og var sundurgreint hvort iðkunin væri á vegum ípróttafélags eða á eigin vegum. Mælingar á ípróttameiðslum voru gerðar út frá fjórum spurningum. Tvær peirra voru staðlaðar spurningar um meiðsli (læknisfræðileg aðstoð síðastliðna 12 mánuði) frá fjölpjóðlegu rannsókninni Heilsa og lífskjör skólabarna (HBSC). ${ }^{21}$ Priðja spurningin var hvort pátttakandi hefði purft að leita til læknis, sjúkrapjálfara eða hjúkrunarfræðings vegna ípróttameiðsla síðastliðna 12 mánuði. Fjórða spurningin snéri að fjarveru frá æfingum og/eða keppni og brottfalli einhvern tímann á ípróttaferlinum. Svarað var fyrir alvarlegustu ípróttameiðslin á ferlinum með peim svarmöguleika að pátttakandi hefði hætt fyrir fullt og allt vegna meiðslanna.

\section{Tölfræðigreining}

Við úrvinnslu gagna var notaður hugbúnaðurinn PAWS, útgáfa 17,0 (SPSS Inc., Chicago, Illinois; www.spss.com). Marktektarmörk voru skilgreind við 0,05. Lýsandi tölfræði var notuð á allar breyt- 
Tafla I. Fjöldi pátttakenda, fæðingarár og vikuleg ástundun skipulagðra iprótta og líkamsræktar.

\begin{tabular}{|c|c|c|c|c|c|c|c|}
\hline & Fjöldi (n) & $\%$ & Karlar (n) & $\%$ & Konur (n) & $\%$ & p-gildi fyrir kynjamun \\
\hline Úrtak & 457 & & 242 & 53 & 215 & 47 & \\
\hline Fæðingarár & & & & & & & 0,629 \\
\hline 1994 (17 ára) & 256 & 56 & 133 & 55 & 123 & 57,2 & \\
\hline 1988 (23 ára) & 201 & 44 & 109 & 45 & 92 & 42,8 & \\
\hline Skipulagðar ípróttir & & & & & & & 0,058 \\
\hline$\geq 2$ sinnum í viku & 163 & 37 & 96 & 41,2 & 67 & 32,4 & \\
\hline Hættir & 277 & 63 & 137 & 58,8 & 140 & 67,6 & \\
\hline Ípróttir/líkamsrækt & & & & & & & 0,001 \\
\hline$\geq 6$ klst á viku & 275 & 66,3 & 132 & 59,2 & 143 & 74,5 & \\
\hline$>6$ klst á viku & 140 & 33,7 & 91 & 40,8 & 49 & 25,5 & \\
\hline
\end{tabular}

ur sem rannsóknin tók til. Meðaltal og staðalfrávik var reiknað fyrir samfelldar breytur, og tíðni og hlutföll fyrir flokkabreytur. Kynjasamanburður var gerður með kí-kvaðratprófi fyrir flokkabreytur en með t-prófi fyrir tvö úrtök fyrir samfelldar breytur. Mælingar á ípróttameiðslum voru bornar saman eftir aldri með kí-kvaðratprófi og reyndist ekki vera marktækur munur á aldurshópunum. Tölfræðigreining var pví ekki aldursskipt. Skoðaðir voru mögulegir áhrifapættir meiðsla (læknisfræðileg aðstoð; já, nei) síðastliðinna 12 mánaða með lógístískri aðhvarfsgreiningu. Skýribreytan var magn íprótta og líkamsræktar ( $\leq 6$ klst/viku og $>6$ klst/viku). Samfelldar skýribreytur voru prek og fituhlutfall. Einnig var gerður samanburður, með t-prófi fyrir tvö úrtök, á holdafari, líkamssamsetningu og preki peirra sem æfa ípróttir og/ eða líkamsrækt í meira en 6 klukkustundir á viku, miðað við pá sem æfa 6 klukkustundir eða minna, skipt eftir kyni.

\section{Niðurstöður}

Allir pátttakendurnir 457 svöruðu spurningalista og voru hæðarog pyngdarmældir, 381 fór í DXA mælingu og 385 náðu gildu prekprófi.

\section{Dátttaka í ípróttum og líkamsrakt}

Sautján pátttakendur (3,7\%) sögðust aldrei hafa tekið pátt í skipulögðu ípróttastarfi en í hópi peirra 440 (96,3\%) sem einhvern tímann höfðu tekið pátt, voru 206 sem sögðust nú að einhverju marki æfa með ípróttafélagi. Í töflu I má sjá að 163 æfðu tvisvar sinnum í viku eða oftar. Sögðust flestir sem æfðu sjaldnar en pað, ekki leggja stund á skipulagðar ípróttir lengur. Pví var tekin ákvörðun um að peir teldust í hópi peirra 277 sem voru hættir. Fjörutíu og tveir pátttakendur (9,2\%) stunduðu hvorki líkamsrækt né ípróttir með ípróttafélagi, 275 æfðu 6 klukkustundir á viku eða minna en 140 æfðu meira en 6 klukkustundir á viku.

\section{Algengi meiddra og brottfall vegna ípróttameiðsla}

Á meðal peirra 206 sem stunduðu ípróttir með ípróttafélagi að einhverju marki, voru 105 (51\%) sem höfðu purft læknisfræðilega aðstoð vegna ípróttameiðsla, einu sinni eða oftar, síðastliðna 12
Tafla II. Fjarvera frá æfingum og/eða keppni og brottfall vegna ípróttameiðsla, einhvern tímann á ípróttaferlinum.

\begin{tabular}{lcc|cc|cc} 
& & & \multicolumn{2}{|c|}{ Karlar } & & \multicolumn{2}{c}{ Konur } \\
$(\mathrm{n}=440)$ & $\%$ & $(\mathrm{n}=234)$ & $\%$ & & $\%$ \\
\hline Aldrei & 183 & 41,6 & 87 & 37,2 & 96 & 46,6 \\
\hline $\begin{array}{l}\text { Styttri en } \\
\text { ein vika }\end{array}$ & 60 & 13,6 & 41 & 17,5 & 19 & 9,2 \\
\hline $\begin{array}{l}1-3 \text { vikur } \\
\text { Lengri en } \\
\text { prjár vikur }\end{array}$ & 72 & 16,4 & 36 & 15,4 & 36 & 17,5 \\
\hline $\begin{array}{l}\text { Hætti vegna } \\
\text { meiðsla }\end{array}$ & 37 & 8,4 & 16 & 6,8 & 21 & 10,2 \\
\hline
\end{tabular}

mánuði. Ef einungis var horft á pá sem æfðu svo til daglega $(n=68)$, var algengið $68 \%$. Ekki var marktækur kynja- eða aldursmunur á pví hvort pátttakendur höfðu purft læknisfræðilega aðstoð.

Tafla II sýnir fjölda einstaklinga er hlutu ípróttameiðsli í skipulögðum ípróttum, sem orsökuðu fjarveru frá æfingum eða keppni, einhvern tímann á ípróttaferlinum. Hlutfall peirra var 58,4\%. Hjá drengjum $62,8 \%$ en $53,4 \%$ hjá stúlkum og var sá kynjamunur marktækur ( $p=0,045$ ). Í töflunni kemur einnig fram hlutfall peirra sem hættu fyrir fullt og allt í ípróttum vegna ípróttameiðsla. Algengi brottfalls var $8,4 \%$ og var hærra hjá stúlkum $(10,2 \%)$ en drengjum $(6,8 \%)$ en kynjamunur var ekki marktækur $(p=0,210)$.

\section{Tengsl ípróttaiðkunar við prek og holdafar}

Tafla III sýnir niðurstöður mælinga á preki, holdafari og líkamssamsetningu, skipt eftir kyni og magni iðkunar. Par kemur fram að peir sem verja meira en 6 klukkustundum á viku við iðkun íprótta og líkamsræktar höfðu meira prek, lægra fituhlutfall og hærra hlutfall fitulauss mjúkvefjamassa (LST) og beinmassa. Konur sem æfðu meira en 6 klukkustundir á viku höfðu að meðaltali 21,7\% hærra prek ( $<<0,001), 12,7 \%$ lægra fituhlutfall $(\mathrm{p}<0,001)$ og 6,7\% hærra hlutfall LST ( $<<0,001)$, heldur en pær sem æfðu 6 klukkustundir á viku eða minna. Hjá körlum sem æfðu meira en 6 klukkustundir á viku var prekið 10\% hærra $(\mathrm{p}<0,001)$, fituhlutfallið 20,6\% lægra $(p<0,001)$, hlutfall LST 6,1\% hærra $(p<0,001)$ og hlutfall beinmassa 7,7\% hærra $(\mathrm{p}=0,002)$ samanborið við karla sem æfðu 6 klukkustundir á viku eða minna. 
Tafla III. Likamlegir eiginleikar pátttakenda sem stunduðu ipróttir og/eða likamsrækt.

\begin{tabular}{|c|c|c|c|c|c|}
\hline & \multicolumn{5}{|c|}{ Vikuleg iðkun skipulagðra íprótta og/eða líkamsræktar } \\
\hline & \multicolumn{2}{|c|}{$\geq 6$ klst $(n=275)$} & \multicolumn{2}{|c|}{$>6$ klst $(n=140)$} & \multirow[b]{2}{*}{$\mathrm{p}$-gildi } \\
\hline & Fjöldi & Meðaltal (SF) & Fjöldi & Meðaltal (SF) & \\
\hline \multicolumn{6}{|l|}{ Konur } \\
\hline Hæð, sm & 143 & $167,0(6,5)$ & 49 & $167,0(5,6)$ & 0,913 \\
\hline Pyngd, kg & 143 & $65,6(11,8)$ & 49 & $63,8(8,2)$ & 0,317 \\
\hline $\mathrm{BMI}, \mathrm{kg} / \mathrm{m}^{2}$ & 143 & $23,4(3,9)$ & 49 & $22,9(3,2)$ & 0,373 \\
\hline Fitumassi, kg & 115 & $21,9(7,8)$ & 47 & $18,7(5,2)$ & 0,01 \\
\hline Fitumassi, \% & 115 & $33,1(6,6)$ & 47 & $28,9(5,3)$ & $<0,001$ \\
\hline LST, kg & 115 & $40,4(4,8)$ & 47 & $42,8(4,6)$ & 0,005 \\
\hline LST, \% & 115 & $63,1(6,5)$ & 47 & $67,2(5,0)$ & $<0,001$ \\
\hline Beinmassi, kg & 115 & $2,4(0,3)$ & 47 & $2,4(0,3)$ & 0,168 \\
\hline Beinmassi, \% & 115 & $3,7(0,5)$ & 47 & $3,8(0,4)$ & 0,075 \\
\hline Prek (W/kg) & 112 & $2,3(0,4)$ & 40 & $2,8(0,4)$ & $<0,001$ \\
\hline \multicolumn{6}{|l|}{ Karlar } \\
\hline Hæð, sm & 132 & $181,0(6,8)$ & 91 & $180,0(6,2)$ & 0,27 \\
\hline Pyngd, kg & 132 & $79,4(19,9)$ & 91 & $76,1(12,2)$ & 0,157 \\
\hline $\mathrm{BMl}, \mathrm{kg} / \mathrm{m}^{2}$ & 132 & $24,1(5,5)$ & 91 & $23,4(3,2)$ & 0,252 \\
\hline Fitumassi, kg & 110 & $18,8(13,6)$ & 74 & $14,2(6,9)$ & 0,008 \\
\hline Fitumassi, \% & 110 & $22,0(8,3)$ & 74 & $17,5(5,9)$ & $<0,001$ \\
\hline LST, kg & 110 & $57,5(7,9)$ & 74 & $61,0(7,2)$ & 0,003 \\
\hline LST, \% & 110 & $74,1(8,1)$ & 74 & $78,6(5,9)$ & $<0,001$ \\
\hline Beinmassi, kg & 110 & $3,0(0,5)$ & 74 & $3,2(0,5)$ & 0,003 \\
\hline Beinmassi,\% & 110 & $3,9(0,6)$ & 74 & $4,2(0,4)$ & 0,002 \\
\hline Prek (W/kg) & 113 & $3,0(0,6)$ & 85 & $3,3(0,5)$ & $<0,001$ \\
\hline
\end{tabular}

Skammstafanir: SF, stađalfrávik; BMI, líkamspyngdarstuðull (body mass index); LST, fitulaus mjúkvefjamassi (lean soft tissue).

\section{Hugsanlegir áhættupættir meiðsla}

Í pessari rannsókn var hópurinn sem stundar bæði æfingar með ípróttafélögum og/eða líkamsrækt á eigin vegum skoðaður sérstaklega $(n=415)$. Af 411 iðkendum sem svöruðu spurningum um ípróttameiðsli voru 126 (30,7\%) sem purftu læknisfræðilega aðstoð (LA) síðastliðna 12 mánuði. Algengara var að hafa leitað sér aðstoðar meðal peirra sem æfðu meira en 6 klukkustundir á viku en meðal peirra sem æfðu 6 klukkustundir á viku eða minna. Í peirra hópi ( $\mathrm{n}=139)$ höfðu 76 leitað sér aðstoðar, en 50 í hópi peirra sem æfðu 6 klukkustundir á viku eða minna $(n=272)$. Við greiningu á pessum niðurstöðum var notuð lógístísk aðhvarfsgreining (tafla IV) og fundið líkindahlutfall pess að hafa purft læknisfræðilega aðstoð síðastliðna 12 mánuði. Reyndust peir sem æfðu meira en 6 klukkustundir á viku vera rúmlega fimm sinnum líklegri til pess, miðað við pá sem æfðu 6 klukkustundir á viku eða minna, par sem ekki var leiðrétt fyrir öðrum páttum (líkan 1). Líkindahlutfallið var svipað pegar leiðrétt hafði verið fyrir preki (líkan 2) og fituhlutfalli (líkan 3). Tengsl meiðsla við prek og fituhlutfall voru ekki marktæk við aðhvarfsgreiningu.

\section{Umræða}

Af 440 ungmennum sem höfðu einhvern tímann stundað ípróttir með ípróttafélagi sögðust 63\% peirra vera hætt en pó aðeins 9,2\% sem sögðust hvorki stunda ípróttir né líkamsrækt. Ípróttameiðsli voru orsök pess að 58,4\% peirra sem einhvern tímann æfðu með ípróttafélögum höfðu sleppt æfingum eða keppni og 8,4\% hættu ípróttapátttöku vegna meiðsla. Algengi meiddra (LA) í ípróttum með ípróttafélagi síðastliðna 12 mánuði var 51\% en 68\% ef skoðaðir voru sérstaklega peir sem æfðu svo til daglega. Peir sem stunduðu ípróttir og líkamsrækt í meira en 6 klukkustundir á viku voru rúmlega 5 sinnum líklegri til pess að hafa meiðst síðastliðna 12 mánuði, en höfðu betra prek, meiri beinmassa, lægra fituhlutfall og hærra hlutfall LST en peir sem æfðu 6 klukkustundir eða minna.

Í hópi karla sögðust 58,8\% vera hættir í ípróttum en 67,6\% kvenna. Svipaður kynjamunur kom fram í íslenskri rannsókn, ${ }^{22}$ en eftir 10 ára ípróttaiðkun unglinga í árgangi 1990, voru 45,9\% stráka og 35,3\% stelpna enn að æfa. Par kom einnig fram að brottfallið reyndist mest í fimleikum og sundi par sem stelpur voru fjölmennari en minnst í fótbolta par sem stelpur voru fámennari. Ólíkt hlutfall kynja í fjölmennum ípróttagreinum getur pví skýrt að hluta kynjamun brottfalls í okkar rannsókn.

Peir sem æfðu meira en 6 klukkustundir á viku voru 5 sinnum líklegri til pess að hafa leitað læknisfræðilegrar aðstoðar síðastliðna 12 mánuði heldur en peir sem æfðu 6 klukkustundir á viku eða minna. Kyn, aldur, prek og fituhlutfall höfðu ekki marktæk tengsl við ípróttameiðsli í aðhvarfsgreiningu. Niðurstöðunum svipar til peirra er fengust hjá Richmond og félögum ${ }^{23}$ sem fundu marktæk tengsl ípróttameiðsla og ípróttapátttöku í klukkustundum á viku, en ekki voru tengsl við kyn og líkamspyngdarstuðul. Hins vegar kemur fram í yfirlitsgrein ${ }^{24}$ að börn og ungmenni sem voru yfir kjörpyngd hafi verið líklegri til pess að meiðast við ípróttaiðkun en iðkendur í kjörpyngd. Einnig eru til vísbendingar um að lélegt prek gæti verið áhættupáttur ípróttameiðsla hjá börnum og fullorðnum. ${ }^{25}$

Hagstæðari líkamlegir eiginleikar peirra sem æfðu meira en 6 klukkustundir á viku gætu verið ávinningur peirra æfinga sem peir höfðu stundað umfram hina. Einnig er mögulegt að peir sem höfðu hagstæðara prek og holdafar vegna erfða og umhverfispátta

Tafla IV. Aðhvarfsgreining á tengslum ípróttameiðsla (LA) síðastliðna 12 mánuði við magn iðkunar.

\begin{tabular}{|c|c|c|c|c|c|c|c|c|}
\hline \multirow[b]{2}{*}{ Vikuleg iðkun } & \multicolumn{2}{|c|}{ Fjöldi (\%) } & \multicolumn{2}{|c|}{ Líkan 1} & \multicolumn{2}{|c|}{ Líkan $2^{\mathrm{a}}$} & \multicolumn{2}{|c|}{ Líkan $3^{\mathrm{b}}$} \\
\hline & Án LA & LA & OR & $95 \% \mathrm{Cl}$ & OR & $95 \% \mathrm{Cl}$ & OR & $95 \% \mathrm{Cl}$ \\
\hline$\geq 6$ klst & $222(81,6)$ & $50(18,4)$ & 1 & Viðmið & 1 & Viðmið & 1 & Viðmið \\
\hline$>6$ klst & $63(45,3)$ & $76(54,7)$ & 5,36 & $3,40-8,43$ & 4,13 & $2,46-6,93$ & 5,3 & $3,00-9,42$ \\
\hline
\end{tabular}

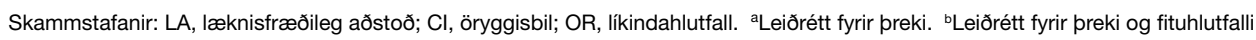


á yngri árum hafi frekar valist í afreksípróttir. ${ }^{26}$ Hlutfall beinmassa hjá körlum, sem æfðu meira en 6 stundir á viku reyndist marktækt hærra en hjá peim sem æfðu minna. Sama gilti ekki um kvennahópana sem höfðu pó tilhneigingu í sömu átt. Líklegt er að kynbundinn munur á hormónabúskap par sem testósteron spilar lykilhlutverk í uppbyggingu vöðva- og beinmassa hjá körlum ${ }^{27}$ ráði einhverju um pær niðurstöður. Við samanburð á iðkunarhópunum kom í ljós að fituhlutfall reyndist betri mælikvarði á holdafar en líkamspyngdarstuðull. Fituhlutfall í hópi peirra sem æfðu meira var marktækt lægra en ekki var marktækur munur á BMI. Munur á holdafarsmælingunum kemur einnig fram í rannsókn ${ }^{28}$ á tengslum holdafars og ípróttameiðsla í neðri útlim. Of pung börn, samkvæmt fituhlutfalli, voru 34\% líklegri til pess að meiðast en börn í kjörpyngd. Hins vegar voru tengslin ekki marktæk pegar BMI var notað sem mælikvarði á of pyngd.

Hátt algengi ípróttameiðsla hjá ungmennum í pessari rannsókn er samhljóma niðurstöðum úr fyrri rannsóknum.4,5,10,11 Ef niðurstöður okkar eru bornar saman við hóprannsóknir sem nota sambærilegar mæliaðferðir og skilgreiningu á meiðslum, má sjá $42 \%$ algengi hjá unglingum 12-15 ára ${ }^{4}, 48 \%$ hjá 15-19 ára ${ }^{5}$ en $51 \%$ hjá ungmennum í okkar rannsókn. Hér var algengið hæst á meðal peirra sem æfðu svo til á hverjum degi, eða $68 \%$ sem er svipað hlutfall og í hópi 14-19 ára kanadískra unglinga $(63,8 \%)^{29}$ sem æfðu 16 klukkustundir á viku eða meira. Pessar háu tölur, sem gætu hugsanlega verið hærri hér en erlendis, eru verulegt áhyggjuefni en ópægindi og verkir sem fylgja ípróttameiðslum eru líkleg til pess að stuðla að neikvæðu viðhorfi gagnvart hreyfingu. Einnig má búast við pví að sá sem hefur hlotið varanlegan áverka sé ekki eins líklegur til pess að lifa virkum lífsstíl og sá sem gengur heill til skógar.

Samkvæmt niðurstöðum gátu ípróttameiðsli verið meginástæða pess að börn og ungmenni hættu að stunda ípróttir en 37 af peim 277 sem voru hættir, hættu fyrir fullt og allt vegna ípróttameiðsla. Meðal norskra ungmenna var hlutfallið heldur lægra par sem $10 \%$ peirra sem hættu í íprótt, hættu vegna ípróttameiðsla. ${ }^{30}$ Hlutföllin eru pó ekki alveg sambærileg pví ekki var vitað hvort norsku unglingarnir hefðu haldið áfram í annarri ípróttagrein. Í okkar rannsókn var kynjamunur á brottfalli vegna meiðsla ekki marktækur, en hlutfallslega höfðu fleiri konur hætt í ípróttum af peim sökum. Vitað er um hærra nýgengishlutfall alvarlegra hnémeiðsla hjá konum í fótbolta, körfubolta ${ }^{13}$ og fimleikum ${ }^{12}$ en vísbendingar eru um að stúlkur eigi frekar á hættu að lenda í slíkum meiðslum í greinum sem fela í sér mikið af stefnubreytingum, hoppi og sprettum. ${ }^{5}$ Prátt fyrir pessa hættu á alvarlegum hnémeiðslum höfðu marktækt fleiri stúlkur aldrei verið fjarverandi vegna ípróttameiðsla. Stúlkur eru taldar líklegri til að lenda í álagsmeiðslum, en strákar í bráðum meiðslum ${ }^{18}$, sem gæti skýrt að einhverju leyti pennan kynjamun. Álagsmeiðsli geta valdið langvarandi eða endurteknum verkjum sem koma ekki endilega í veg fyrir iðkun en eru líklegir til pess að skerða hæfni og breyta ánægju af ástundun ípróttanna í kvöð.

Í ljós kom að stór hluti $(58,4 \%)$ peirra ungmenna sem hafði einhvern tímann æft ípróttir sagðist hafa átt í ípróttameiðslum sem ollu fjarveru frá iðkun og brottfalli einhvern tímann á ferlinum. Hátt algengi (68\%) peirra sem purftu að leita sér læknisfræðilegrar aðstoðar síðastliðið ár meðal peirra sem æfðu svo til á hverjum degi, gefur tilefni til pess að ætla að mikið æfinga- og keppnisálag geti verið orsök meiðsla í mörgum tilvikum. Pví er hugsanlegt að vel ígrundaðar skipulagsbreytingar á ípróttastarfi, sem hefðu að markmiði að minnka álag, gætu fækkað meiðslum. Ekki er augljóst hvernig best væri að minnka álag en hafa verður í huga í pví sambandi að ípróttameiðsli ungmenna eru um pað bil prisvar sinnum líklegri við keppni en æfingar. ${ }^{12,13,17}$ Pví getur ekki talist heppilegt fyrir iðkendur að keppa bæði með sínum flokki og peim næsta fyrir ofan. Einnig má benda á að heilbrigðismenntaðir starfsmenn eru í fæstum tilfellum starfandi á vegum ípróttafélaga fyrr en komið er upp í efstu deildir. Með aukinni aðkomu sjúkrapjálfara að ípróttastarfi barna og unglinga væri mögulega hægt að bæta endurhæfingu eftir bráð meiðsli, fyrirbyggja framgang álagseinkenna á fyrstu stigum og koma með pví í veg fyrir endurtekna verki og keðjuverkandi meiðslaframgang.

Helstu gallar pessarar rannsóknar eru sjálfsskráðar afturskyggnar mælingar á reglubundinni hreyfingu pátttakenda sem var pá hugsanlega ofmetin. Afturskyggnir spurningalistar geta einnig haft í för með sér óáreiðanlegar niðurstöður vegna gleymsku en brottfall úr íprótt vegna meiðsla og pjónusta fagaðila í heilbrigðispjónustu eru pó líkleg atriði til pess að vera í fersku minni. Einnig er ljóst að niðurstöður pversniðsrannsóknar sem pessarar er ekki hægt að yfirfæra á pýði eða aðra hópa en voru í pessari rannsókn. Til helstu kosta rannsóknarinnar má nefna fjölda pátttakenda sem gerði tölfræðilegt afl nægjanlegt fyrir pá tölfræðigreiningu sem var fyrirhuguð í upphafi. DXA-mælingar á líkamssamsetningu og holdafari í svo fjölmennum hópi gefur pessari rannsókn einnig aukið vægi. Pá telst gott að pátttakendur höfðu búsetu víðs vegar um landið en algengi meiddra ræðst að nokkru leyti af pví hvaða ípróttir eru í boði á hverju svæði fyrir sig.

\section{Ályktun}

Á heimsvísu skortir rannsóknir á ípróttameiðslum barna og unglinga en pær fáu rannsóknir sem til eru benda til pess að algengið sé hátt. Staðan meðal íslenskra ungmenna virðist síst betri og í sumum tilfellum valda meiðsli brottfalli úr ípróttum. Pví er nauðsynlegt að efla íslenskar rannsóknir til pess að fá vitneskju um hvort ípróttameiðsli séu algengari hér á landi en annars staðar. Einnig parf að rannsaka betur orsakir ípróttameiðsla svo hægt verði að efla forvarnir, koma í veg fyrir brottfall og tryggja pjálfun sem byggir á gagnreyndum aðferðum. Pörf er á kynjaskiptum rannsóknum á almennu brottfalli úr ípróttum en fyrir liggja vísbendingar um hærra brottfall meðal stúlkna.

\section{Pakkir}

Pakkir fá ungmennin sem tóku pátt í rannsókninni, samstarfsmenn frá Háskóla Íslands og Háskólanum á Akureyri, ásamt peim mörgu sem voru hjálplegir par sem mælingar fóru fram. Jóhanna Eyrún Torfadóttir lýðheilsufræðingur fær einnig pakkir fyrir góð rád við tölfræðiúrvinnslu. Rannsóknin var styrkt af Rannís, Lýðheilsusjóði, Embætti landlæknis, Ípróttasjóði Mennta- og menningarmálaráđuneytis, Rannsóknarsjóði HÍ, Hjartavernd, Landsbankanum, Símanum, Icepharma og Bílaleigu Akureyrar. 


\section{Heimildir}

1. Caine D, DiFiori J, Maffulli N. Physeal injuries in children's and youth sports: reasons for concern? Br J Sports Med 2006; 40: 749-60.

2. Blair SN. Physical inactivity: the biggest public health problem of the 21st century. Br J Sports Med 2009; 43: 1-2.

3. Haskell WL, Lee IM, Pate RR, Powell KE, Blair SN, Franklin BA, et al. Physical activity and public health Updated recommendation for adults from the American college of sports medicine and the American heart association. Circulation 2007; 116: 1081-93.

4. Emery CA, Tyreman H. Sport participation, sport injury, risk factors and sport safety practices in Calgary and are unior high schools. Paediatr Child Health 2009; 14: 439-44.

5. Emery CA, Meeuwisse WH, McAllister JR. Survey of sport participation and sport injury in Calgary and area high schools. Clin J Sport Med 2006; 16: 20-6.

6. Maffulli N, Longo UG, Gougoulias N, Caine D, Denaro V. Sport injuries: a review of outcomes. Br Med Bull 2011; 97 : $47-80$.

7. Maffulli N, Longo UG, Gougoulias N, Loppini M, Denaro $\mathrm{V}$. Long-term health outcomes of youth sports injuries. B J Sports Med 2010; 44: 21-5.

8. Oiestad BE, Holm I, Engebretsen L, Aune AK, Gunderson $\mathrm{R}$, Risberg MA. The prevalence of patellofemoral osteoarthritis 12 years after anterior cruciate ligament reconstruction. Knee Surg Sports Traumatol Artrosc 2013; 21: 942-9.

9. Kerssemakers SP, Fotiadou AN, de Jonge MC, Karantanas $\mathrm{AH}$, Maas M. Sport injuries in the paediatric and adolescent patient: a growing problem. Pediatr Radiol 2009; 39: $471-84$

10. Cuff S, Loud K, O'Riordan MA. Overuse Injuries in High School Athletes. Clin Pediatr 2010; 49: 731-6.

11. Frisch A, Seil R, Urhausen A, Croisier JL, Lair ML, Theisen D. Analysis of sex-specific injury patterns and risk factors in young high-level athletes. Scand J Med Sci Sports 2009; 19: 834-41.
12. Hootman JM, Dick R, Agel J. Epidemiology of collegiate injuries for 15 sports: Summary and recommendations for injury prevention initiatives. J Athl Training 2007; 42: 311-

13. Darrow CJ, Collins CL, Yard EE, Comstock RD Epidemiology of Severe Injuries Among United States High School Athletes 2005-2007. Am J Sports Med 2009; 37: 1798-805.

14. Roos EM. Joint injury causes knee osteoarthritis in young adults. Curr Opin Rheumatol 2005; 17: 195-200.

15. Leroux T, Ogilvie-Harris D, Dwyer T, Chahal J, Gandhi R, Mahomed N, et al. The Risk of Knee Arthroplasty Following Cruciate Ligament Reconstruction A Population-Based Matched Cohort Study. J Bone Join Surg Am 2014; 96A: 2-10.

16. Knowles SB, Marshall SW, Bowling JM, Loomis D, Millikan R, Yang JZ, et al. A prospective study of injury incidence among North Carolina high school athletes. Am J Epidemiol 2006; 164: 1209-1221.

17. Rechel JA, Yard EE, Comstock RD. An epidemiologic comparison of high school sports injuries sustained in practice and competition. J Athl Train 2008; 43: 197-204.

18. Yang J, Tibbetts AS, Covassin T, Cheng G, Nayar S, Heiden E. Epidemiology of Overuse and Acute Injuries Among Competitive Collegiate Athletes. J Athl Train 2012; 47: 198204.

19. DiFiori JP, Benjamin HJ, Brenner JS, Gregory A, Jayanth $\mathrm{N}$, Landry GL, et al. Overuse injuries and burnout in youth sports: a position statement from the American Medical Society for Sports Medicine. Br J Sports Med 2014; 48: 287-8.

20. Tammelin T, Nayha S, Hills AP, Jarvelin MR. Adolescent participation in sports and adult physical activity. Am J Prev Med 2003; 24: 22-8.
21. Molcho M, Harel Y, Pickett W, Scheidt PC, Mazur J, Overpeck MD, et al. The epidemiology of non-fatal injuries among 11-, 13- and 15-year old youth in 11 countries: findings from the 1998 WHO-HBSC cross national survey. Int J Inj Contr Saf Promot 2006; 13: 205-11.

22. Hilmarsdóttir RH. Ípróttapátttaka og brottfall. Greining á íbróttabátttöku barna og unglinga fæddra 1990 og 1995 á árunum 1994 og 2009. MS-ritgerð, hjúkrunarfræðideild, Háskóla Íslands 2011.

23. Richmond SA, Kang J, Emery CA. Is body mass index a risk factor for sport injury in adolescents? J Sci Med Sport 2013; 16: 401-5.

24. McHugh MP. Oversized young athletes: a weighty concern. Br J Sports Med 2010; 44: 45-9.

25. Emery CA. Risk factors for injury in child and adolescent sport: A systematic review of the literature. Clin J Sport Med 2003; 13: 256-68.

26. Phillips E, Davids K, Renshaw I, Portus M. Expert Performance in Sport and the Dynamics of Talent Development. Sports Med 2010; 40: 271-83.

27. Lang TF. The bone-muscle relationship in men and women. J Osteoporos 2011; 2011: 702-35.

28. Jespersen E, Verhagen E, Holst R, Klakk H, Heidemann M, Rexen $\mathrm{CT}$, et al. Total body fat percentage and body mass index and the association with lower extremity injuries in children: a 2.5-year longitudinal study. Br J Sports Med 2014; 48: 1497-501.

29. Rose MS, Emery CA, Meeuwisse WH. Sociodemographic predictors of sport injury in adolescents. Med Sci Sports Exerc 2008; 40: 444-50.

30. Seippel $\varnothing$. Orker ikke, gidder idde, passer ikke? Om frafallet í norsk idrett. Institutt for samfunnsforskning, Oslo 2005.

ENGLISH SUMMARY

\section{Prevalence of sport injuries, sport participation and drop out due to injury in young adults}

Indridadottir $\mathrm{MH}^{1}$, Sveinsson $\mathrm{T}^{2}$, Magnusson $\mathrm{KT}^{1}$, Arngrimsson $\mathrm{SA}^{1}$, Johannsson $\mathrm{E}$

Introduction: Sport participation has increased during the past few decades, with accompanying rise in sport injuries. The purpose of this study was to assess the prevalence of sport injuries, and drop-out due to them along with possible risk factors (hours of sports participation, sex, age, aerobic fitness and body composition).

Material and methods: A retrospective, cross-sectional design was used and the 457 participants were 17 and 23 years old. Height, weight, body fat, lean soft tissue, bone mass, and aerobic fitness $(\mathrm{W} / \mathrm{kg})$ were measured. Participation in sports and physical training, and the prevalence of sport injuries and drop-out were estimated using questionnaires.

Results: Four hundred and forty participants (96\%) had at some time point participated in organized sports, but 277 (63\%) were no longer practicing, more commonly $(\mathrm{p}=0.058)$ among girls $(67.6 \%)$ than boys (58.8\%). Thirty-seven (8.4\%) dropped-out due to sport injuries. Of those participating in organized sports for the past 12 months, $51 \%$ required medical assistance at least once because of sport injuries. Multiple regression analysis revealed 5 -fold increased risk for requiring medical assistance among those practicing more than 6 hours per week compared to those who practiced 6 hours or less (OR $=5.30,95 \% \mathrm{Cl}: 3.00$ to 9.42 ). Conclusion: Youth sport injuries are a significant problem that can cause drop-out from participation in sport. More research is needed to better understand the impact of risk factors in order to promote prevention and ensure evidence-based training.

${ }^{1}$ Research Centre for Sport and Health Sciences, School of Education, University of Iceland, ${ }^{2}$ Research Centre of Movement Sciences, School of Health Sciences, University of Iceland. Key words: Sport injury, drop-out, young adults, risk factor, prevalence.

Correspondence: Erlingur Jóhannsson, erljo@hi.is 